\title{
ESBOZO DE LUIS ASTEY
}

Alma Wood de Astey*

Conocí a Luis en otoño de 1965, cuando ingresé al Tecnológico de Monterrey. Fue mi profesor tanto en la licenciatura como en la maestría de Letras Hispánicas. Luis era famoso en el Tecnológico como el profesor que todo lo sabía; durante años impartió la clase de Historia de la Cultura, que era obligatoria para prácticamente todas las carreras.

Tuve la suerte de que me asesorara en mi tesis de licenciatura y aprendí mucho con él. En el verano de 1973 nos casamos y en el otoño del mismo año nos vinimos a vivir a México, pues gracias a Francisco Gil, quien había sido su alumno, Luis fue invitado a colaborar en el ITAM. En esa misma época ingresó a la UNAM como profesor de asignatura de la materia de Literatura Medieval Española, que impartió durante casi 25 años, y más tarde, en los ochenta, se integró a $\mathrm{El}$ Colegio de México como investigador.

Siempre admiré a Luis no sólo por su inteligencia sino también por su sensibilidad. Era muy apasionado en todo lo que hacía, y no sólo en sus clases e investigaciones. Igual se le veía desencuadernar y lavar con cloro algún libro que tuviera manchas de humedad, que buscar el libro más especializado para disecar mariposas, ya que algún tiempo nos dedicamos a coleccionarlas.

Termino este pequeño esbozo con uno de sus poemas:

* Universidad Autónoma Metropolitana-Iztapalapa. 
ALMA WOOD DE ASTEY

\author{
Árbol y flor \\ por el gajo que se desgarra \\ desciende el júbilo \\ y es la semilla \\ raíz del mundo.
}

